\title{
PERANGKAT LUNAK JAJAK PENDAPAT (VOTING) BERBASIS SHORT MESSAGE SERVICE (SMS) GATEWAY DAN WEB
}

\author{
Novendra Adisaputra Sinaga ${ }^{1)}$, Andi Setiadi Manalu ${ }^{2)}$ Benjamin Albert Simamora ${ }^{3)}$ \\ ${ }^{1}$ Komputerisasi Akuntansi, Politeknik Bisnis Indonesia \\ email: mrnoven@gmail.com \\ ${ }^{2}$ Teknik Komputer, Politeknik Bisnis Indonesia \\ email: Andi.manaloe@gmail.com \\ ${ }^{3}$ Keuangan dan Perbankan, Politeknik Bisnis Indonesia \\ email: bjmmora@gmail.com
}

\begin{abstract}
One of the characteristics of democracy is characterized by direct elections. Nowadays the role of technology greatly affects all aspects of life because it is more effective and accurate. Electronic voting or $e$-voting is the usual form of voting used for general elections and polls using electronic media. The shift in the conventional election process in today's technological era utilizes the media for polling, one of which is short message service (SMS). The use of Short Message Service (SMS) technology can now be utilized for voting because it is supported by many factors including availability, speed, security and accuracy of data generated. Voting Based on Short Message Service (SMS) and relatively cheap costs so as to make it easier for users, both voting participants and voting implementers, to be more optimal.
\end{abstract}

Keywords: SMS, Gateway, Voting, Democracy, Web

\section{PENDAHULUAN}

Politeknik Bisnis Indonesia (PBI) merupakan salah satu Politeknik di Pematangsiantar yang terdiri dari 4 Program Studi yang terdiri dari \pm 400 Mahasiswa. Badan Eksekutif Mahasiswa (BEM) PBI merupakan organisasi yang dimiliki mahasiswa disebuah perguruan tinggi baik universitas atau Politeknik. Fungi BEM sebagai forum perwakilan seluruh mahasiswa PBI. Badan Eksekutif Mahasiswa (BEM) PBI ini tentunya memiliki anggota yang tidak sedikit selama ini proses pemilihan ketua BEM diruang lingkup Badan Perwakilan Mahasiswa (BPM) masih dilaksanakan secara manual. Proses voting dilakukan dengan mengguanakan kertas suara, setelah itu hasil voting akan di gabungkan, setelah hasil pemilihan sudah terkumpul semua baru dilakukan perhitungan suara [3].

Metode pemilihan dengan cara manual sangat kurang efektif dan efisien karena masalah yang sering dihadapi dalam penggunaan voting pemilihan ketua BEM PBI adalah proses pemilihan masih secara konvensional yaitu mencontreng salah satu kandidat calon ketua yang tertera dikertas. Pengarsipan pengelolaan data pemilih masih belum tertata rapi selain itu kendala yang sering dihadapi adalah bentrok waktu antara jadwal kegiatan pemilihan dengan waktu kuliah mahasiswa.

Penggunaan voting sebagai media untuk mencari keputusan yang berkaitan dengan hajat hidup orang banyak telah dimulai sejak lama. Dalam pelaksanaannya, banyak terjadi penyimpangan yang dilakukan oleh sebagian golongan masyarakat untuk kepentingan mereka sendiri. Hal ini menyebabkan timbulnya konflik di masyarakat, serta menurunnya tingkat kepercayaan masyarakat terhadap pihak penyelenggara voting dan pihak pemenang voting tersebut [5].

Memanfaatkan Fasilitas Short Message Service (SMS) adalah fasilitas dalam teknologi seluler GSM yang memungkinkan pengguna mengirim dan menerima pesan pendek di telepon selulernya, dari teknologi tersebut, dengan menggunakan teknologi short message service di desain dan dikembangkan menjadi SMS gateway untuk melakukan voting dalam pemilihan Ketua BEM PBI secara transparent, akurat, tepat dan cepat. Pemilihan teknologi SMS Gateway pada penelitian ini dikarenakan keluasan jangkauan sinyal dari smartphone yang sudah menjadi kecenderungan dimiliki setiap orang [1]-[4] dan 
dipadukan dengan Aplikasi Web yang lebih dominan dalam membangun sistem yang mengelola administasi dan pembuatan laporan [7].

\section{METODE PENELITIAN}

Perangkat Lunak Jajak Pendapat (Voting) Berbasis Short Message Service (SMS) Gateway Dan Web (Studi Kasus : Pemilihan Ketua BEM di Politeknik Bisnis Indonesia) ini dilakukan dengan menggunakan pemodelan Prototype. Pemilihan Prototype ini karena dianggap lebih cepat dalam pengembangannya, yaitu dengan membuat model perangkat lunak yang diinginkan. Model perangkat lunak tersebut kemudian dievaluasi dan diperbaiki. Apabila dianggap sudah layak, maka perangkat lunak tersebut langsung diproduksi, sedangkan apabila masih ada kekurangan, maka dilakukan perbaikan. Pengembangan dari perancangan sistem tersebut menggunakan tahap siklus pengembangan model prototype yaitu [7] :

1. Komunikasi.

Pada tahap ini dilakukan pertemuan dengan pihak customer untuk mendeskripsikan spesifikasi kebutuhan yang diketahui saat itu.

2. Perencanaan Secara Cepat.

Hasil dari tahap pertama dijadikan sebagai dasar ide (konsep) untuk pemodelan dalam bentuk "rancangan cepat".

3. Modeling Quick Design.

Pada tahap ini dilakukan pemodelan perencanaan sebelumnya dengan menggunakan beberapa model dengan menggunakan tools DFD.

4. Pembuatan Prototype

Selanjutnya pada tahapan ini Rancangan cepat merupakan dasar untuk memulai konstruksi pembuatan prototipe misalnya rancangan antarmuka pengguna dengan menggunakan tools Balsamiq.

5. Complete Software.

Prototype yang telah dibuat di evaluasi dan diberikan umpan-balik untuk memperbaiki spesifikasi kebutuhan. Setelah disetujui (berhasil dengan sukses memenuhi spesifikasi yang diajukan) oleh user selanjutnya user dapat menggunakan program.

\subsection{Analisis Kebutuhan}

Analisis kebutuhan digunakan untuk mengidentifikasi kebutuhan terhadap sistem baru.

1. Perangkat Keras (Hardware)

Adapun hardware yang digunakan dalam pengembangan jajak pendapat (voting) dengan SMS Gateway berbasis web adalah :

a. Procesor AMD Dual-Core Procesor C50(1.0 GHZ)

b. RAM DRD3 2 GB

c. Modem

d. Operator Mobile (SIM Card)

2. Perangkat Lunak (Software)

Adapun kebutuhan yang dibutuhkan adalah database server seperti dibawah ini:
a. Gammu
b. Xampp
c. PHP
d. MySQL
e. Notepad ++

\subsection{Diagram Konteks}

Diagram konteks adalah diagram yang terdiri dari suatu proses dan menggambarkan ruang lingkup suatu sistem. Diagram Konteks ini merupakan bagian dari level tertinggi dari DFD (Data Flow Diagram) yang menggambarkan seluruh input ke suatu sistem atau output dari sistem. Ia akan memberi gambaran mengenai keseluruhan dari sistem. Sistem dibatasi oleh Boundary (dapat digambarkan dengan garis putus). Diagram Konteks pada sistem dapat dilihat pada gambar 1 .

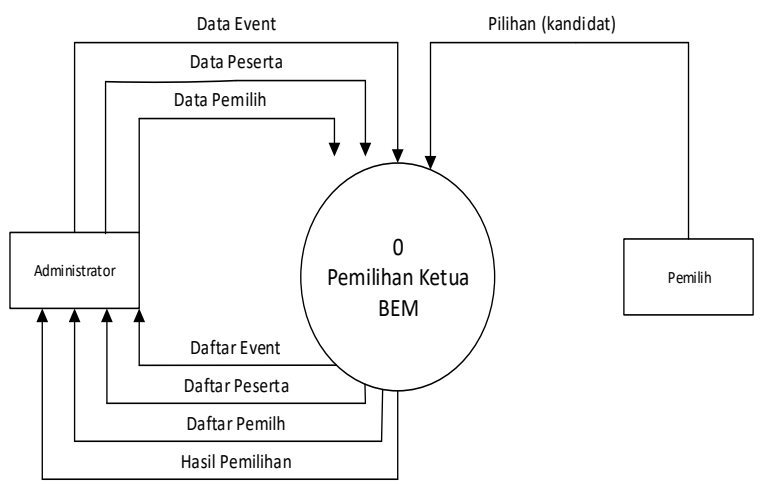

Gambar 1. Diagram konteks Usulan

Dari diagram diatas terdapat 2 entitas yaitu entitas Administrator dan Pemilih. Pada Entitas Administrator menginput data event, data peserta 
dan data pemilh ke dalam sistem. Data yang telah di input oleh administrator ke dalam sistem hanya dapat dilihat dan di akses oleh administrator. Pada entitas pemilih hanya menginput data pilihan (kandidat) dengan cara mengirim pesan dengan format yang telah di tentukan atau memilih secara langsung melalui web dan hasilnya hanya dapat di akses oleh administrator.

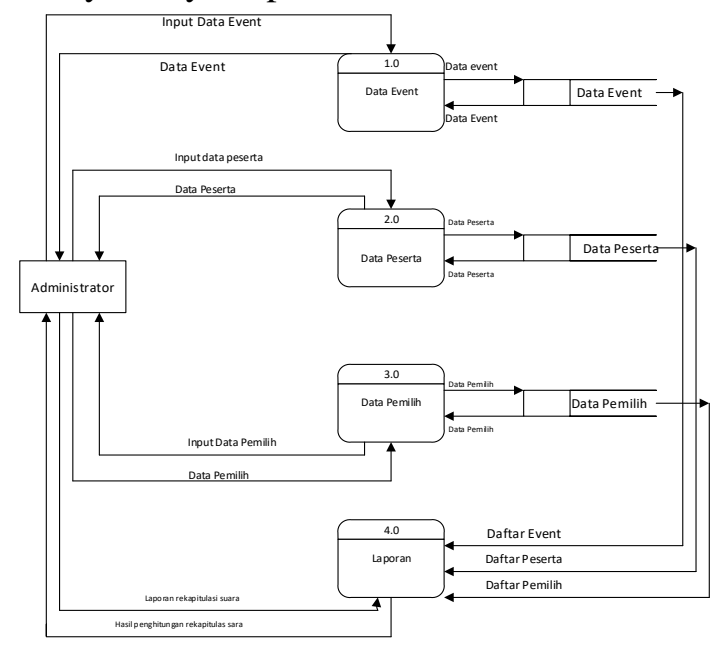

Gambar 2. DFD Level 0 usulan

\subsection{Perancangan Antar Muka}

Perancangan antar muka dibuat untuk menampilkan rancangan yang akan diusulkan pada aplikasi yang akan dibangun

1. Rancangan Halaman Data Peserta

Rancangan halaman data peserta adalah halaman yang dibutuhkan oleh sistem untuk mengimput data peserta kedalam sistem, di halaman data peserta di tentukan siapa yang berhak menjadi peserta atau kandidat dalam event. Adapun rancangan halaman data peserta dapat dilihat pada gambar berikut:

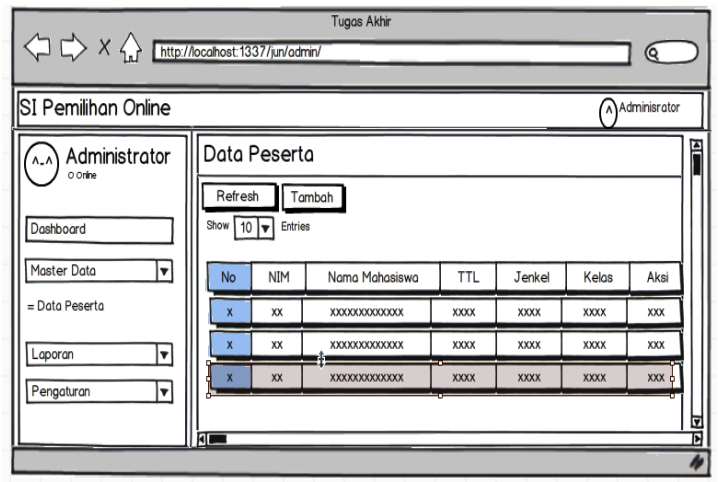

Gambar 3. Halaman Input Data Peserta
2. Rancangan Halaman Data Pemilih Rancangan halaman pemilihan adalah halaman yang berfungsi sebagai halaman untuk menampilkan event yang sedang berlangsung, dan juga nenampilkan no. urut peserta beserta foto peserta yang berhak untuk dipilih. Adapun rancangan dari event pemilihan dapat dilihat pada gambar berikut:

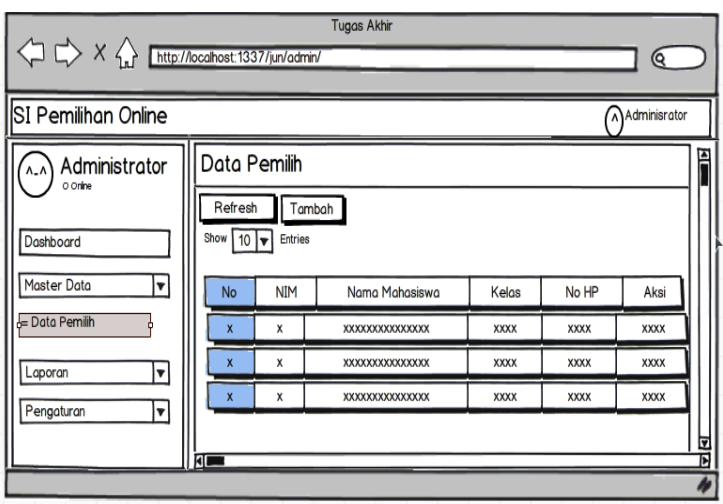

Gambar 4. Halaman Data Pemilihan

3. Konfigurasi Gammurc

Setelah aplikasi gammu di instal pada PC, kemudian masuk ke direktori C:IProgram Files (x86)\Gammu 1.33.0 \bin.

Kemudian file gammurc di pindahkan ke direktori C: $\backslash$ Userslok\AppDatalRoaming.

Setelah itu, pada file gammurc ubah konfigurasi sesuai dengan alamat atau posisi modem. Konfigurasi gammurc dapat dilihat pada gambar berikut:

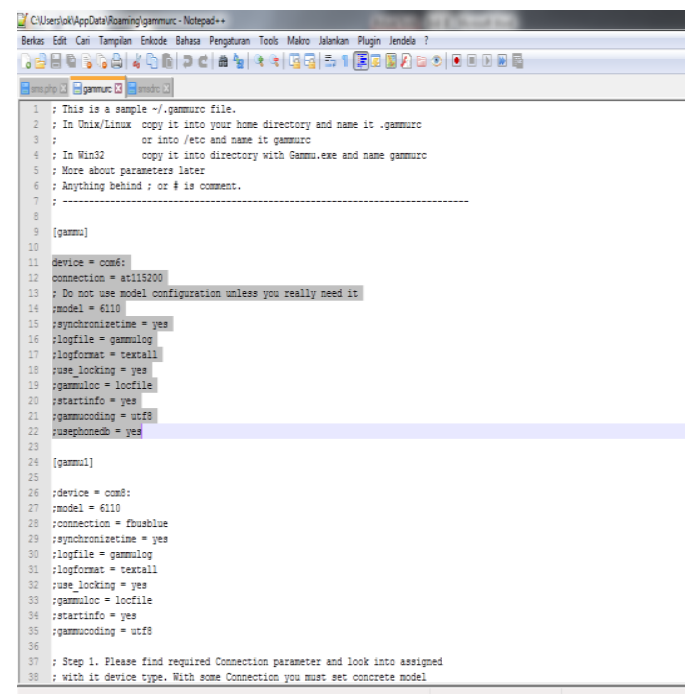

Gambar 5. Konfigurasi gammurc 
4. Cek Konfigurasi dengan CMD

Setelah konfigurasi gammurc dan smsdrc kemudian aplikasi gammu di cek pada $\mathrm{cmd}$ apakah aplikasi gammu sudah terinstal atau tidak pada direktori. Instalasi gammu pada cmd dapat dilihat pada gambar berikut:

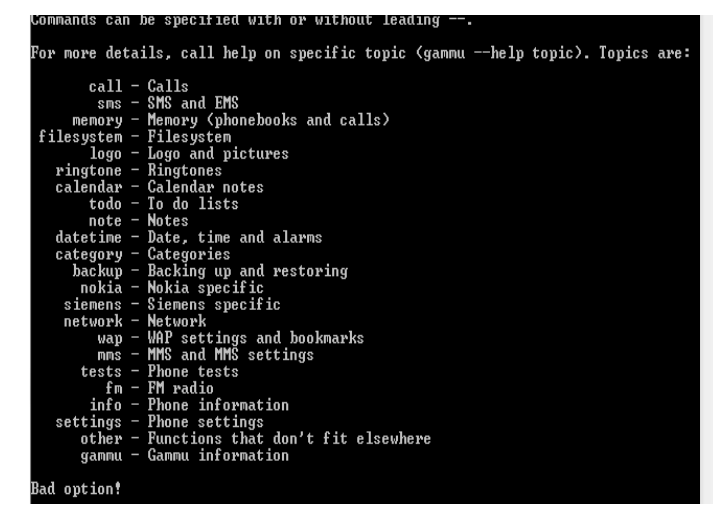

Gambar 6. Cek Konfigurasi Gammu di cmd

\section{HASIL DAN PEMBAHASAN}

Hasil implementasi dari Perangkat Lunak Jajak Pendapat (Voting) Berbasis Short Message Service (SMS) Gateway Dan Web (Studi Kasus : Pemilihan Ketua BEM di Politeknik Bisnis Indonesia)

\subsection{Implementasi Halaman Login}

Halaman $\log$ in terdiri dari dua menu yaitu log in pemilih dan Admin. Log in pemilih untuk mahasiswa yang berhak memilih dan datanya telah terdaftar, apabila data belum terdaftar maka tidak bisa memilih melalui web dan tidak akan terbaca di data base. Login admin untuk administrator yang akan mengimput data ke dalam master data, seperti pada Gambar 7.

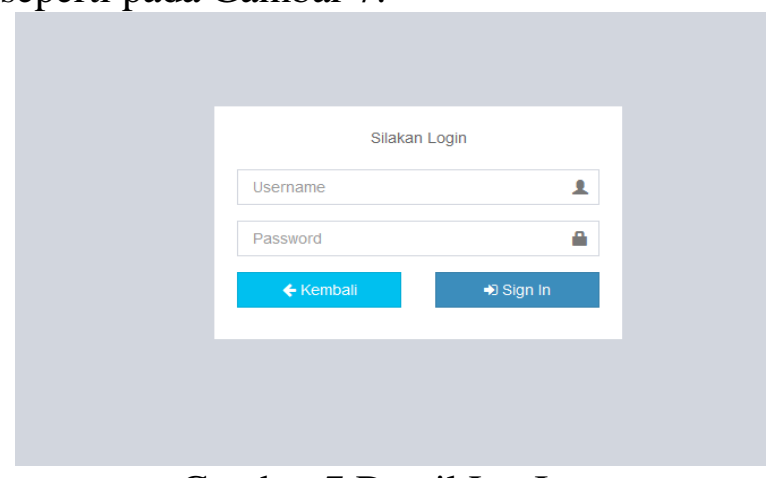

Gambar 7 Detail LogIn

\subsection{Implementasi Halaman Pemilih}

Halaman pemilih terdiri dari event pemilihan dan kandidat yang berhak dipilih. Setelah Log in ke halaman pemilih menentukan pilihan dengan menceklis kandidat, maka data akan disimpan di database dan hasilnya akan di tampilkan dala bentuk grafik, seperti pada Gambar 8.

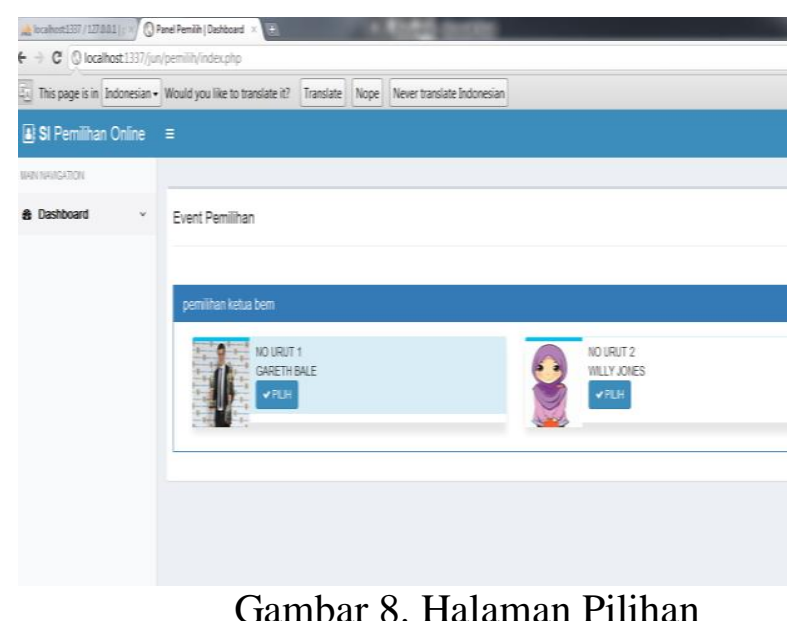

\subsection{Implementasi Halaman Pemilih}

Halaman data peserta berfungsi untuk menampilkan data peserta yang berhak dipilih oleh pemilih dan data tersebut masih dapat di ubah atau di hapus dari form data peserta, seperti pada Gambar 9.

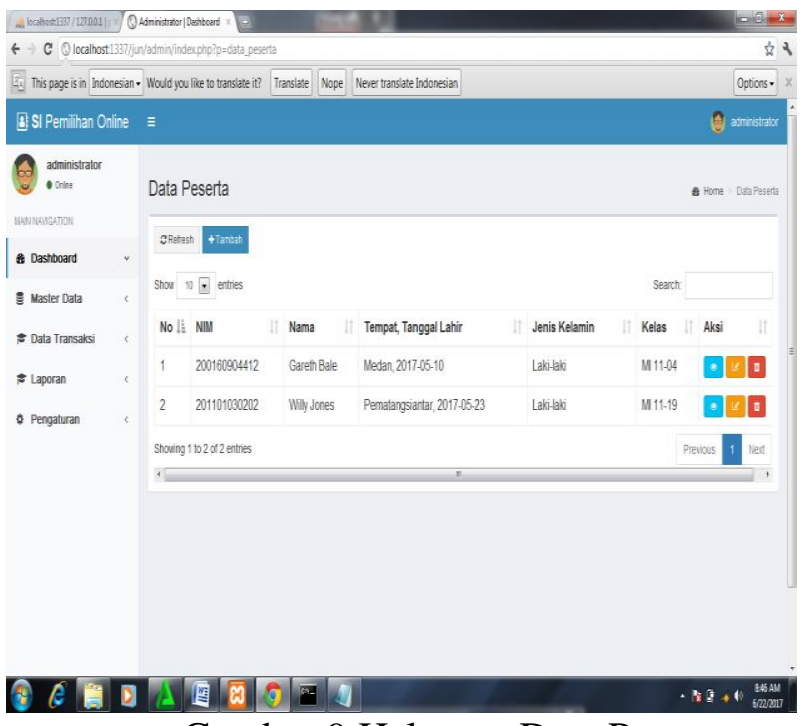

Gambar 9 Halaman Data Peserta 


\subsection{Implementasi Halaman Laporan Rekapitulasi Suara}

Halaman rekapitulasi suara berfungsi untuk menampilkan hasil dari event pemiliha Ketua BEM, seperti pada gambar 10.

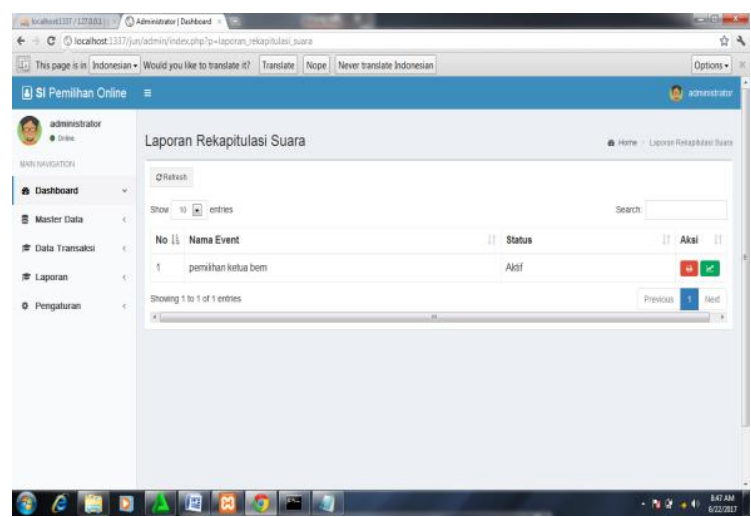

Gambar 10. Halaman Laporan Rekapitulasi

\section{KESIMPULAN}

Setelah melakukan Perancangan dan Implementasi Perangkat Lunak Jajak Pendapat (Voting) Berbasis Short Message Service (SMS) Gateway Dan Web (Studi Kasus : Pemilihan Ketua BEM di Politeknik Bisnis Indonesia) maka dapat diambil kesimpulan sebagai berikut :

1. Mahasiswa lebih mudah melaksanakan proses pemilihan Ketua BEM dan pemilihan event lainnya di PBI.

2. Hasil pengujian dari pemamfaatan teknologi SMS Gateway dalam perangkat lunak voting, sudah berjalan sesuai dengan kebutuhan yaitu dapat melakukan voting melalui SMS. Sedangkan untuk informasi voting dan informasi pelaksanaan event hanya bisa di akses oleh administrator pada web.

3. Aplikasi jajak pendapat (voting) ini juga dapat dilakukan untuk pemilihan event lainnya, akan tetapi masih manual yaitu terlebih dahulu mengosongkan data pada tabel inbox.

\section{REFERENSI}

[1] Azwanti, N. (2017). Perancangan E-
Voting berbasis Web. Jurnal Komputer Terapan, 3(2), 119-132.

[2] Fitriandi, A., Komalasari, E., \& Gusmedi, H. (2016). Rancang Bangun Alat Monitoring Arus dan Tegangan Berbasis Mikrokontroler dengan SMS Gateway. Jurnal Rekayasa dan Teknologi Elektro, 10(2), 87-98.

[3] Hardianti, S., \& Yudhihartanti, Y. (2016). Model Aplikasi E-Voting Berbasis WEB Pada Pemilihan Ketua Badan Eksekutif Mahasiswa. Jutisi: Jurnal Ilmiah Teknik Informatika dan Sistem Informasi, 4(2).

[4] Ibrahim, A. (2011). Pengembangan Sistem Informasi Monitoring Tugas Akhir Berbasis Short Message Service (SMS) Gateway di Fasilkom Unsri. Jurnal JUSI, $1(2), 81-92$.

[5] Risnanto, S. (2017). Aplikasi Pemungutan Suara Elektronik/E-Voting Menggunakan Teknologi Short Message Service dan At Command. Jurnal Teknik Informatika, 10(1).

[6] Sinaga, N. A., \& Sirait, S. (2019). SISTEM INFORMASI ADMINISTRASI KEPENDUDUKAN (STUDI KASUS: DESA PARSAORAN AJIBATA KECAMATAN AJIBATA KABUPATEN TOBA SAMOSIR). Jurnal Teknik Informasi dan Komputer (Tekinkom), 2(2), 137-144.

[7] Siregar, V. M., Sugara, H., \& Purba, G. A. (2019). APLIKASI PENCATATAN LAPORAN PENJUALAN KITA-KITA. NET BERBASIS WEB. Jurnal Teknik Informasi dan Komputer (Tekinkom), 2(1), 80-86. 